\title{
Investigating the impact of antecedents of internal audit function effectiveness at a private university in Ghana
}

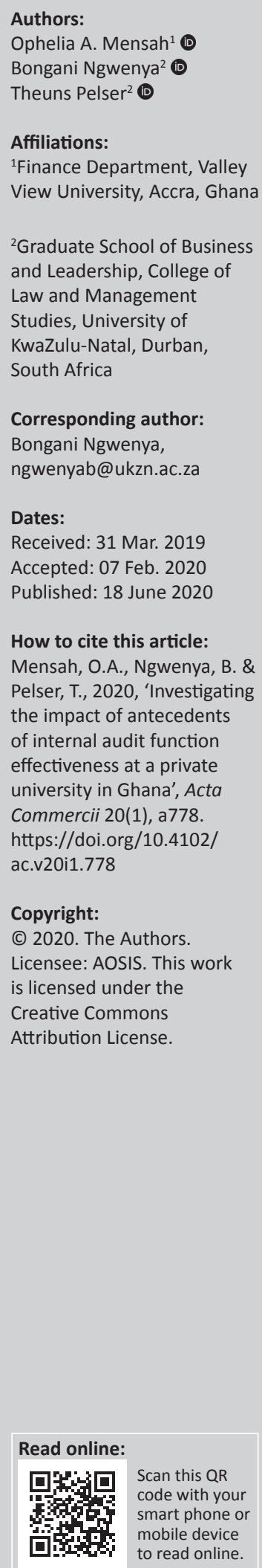

Orientation: The need for sound corporate governance has directed attention to internal auditing as a corporate governance tool and mechanism in both public and private sector organisations.

Research purpose: The study examined the impact of management support and commitment, staff competence and independence of internal auditors as the antecedents of the effectiveness of an internal auditing function.

Motivation for the study: This study was motivated by the need to assess the effectiveness of internal auditing as a corporate governance tool in a non-profit organisation.

Research design, approach and methods: A quantitative case study design was employed in this study. A structured questionnaire was administered to 250 respondents, systematic randomly selected from a target population of 480 . Data collected were analysed descriptively and inferentially. The inferential statistics employed were correlation and multiple regression.

Main findings: The results reveal that, independence of the internal auditing staff (mean = 6.05 , standard deviation $[\mathrm{SD}]=1.032$ ); their competence (mean $=6.00, \mathrm{SD}=1.132$ ); and support and commitment of management (mean $=4.80, \mathrm{SD}=1.679$ ) have impact on the effectiveness of internal auditing (mean $=6.44, \mathrm{SD}=0.863)$. Further more, the antecedents $\left(r=0.834^{*}, r^{2}=0.686\right.$, $p<0.01$, adj. $r^{2}=0.677$ ) have a positive correlation with internal audit effectiveness, and collectively account for $68.6 \%$ of the effectiveness of internal audit function.

Practical/managerial implications: Management should ensure, (1) full support and commitment to the internal auditing function; (2) adequate resources are available; (3) appropriate skills and experience and (4) consistent training and development of internal auditing staff.

Contribution/value-add: This study extends the academic debate on internal auditing as a corporate governance tool of managing the agency problem inherent in non-profit organisations.

Keywords: internal audit; internal control; audit independence; management support; management commitment.

\section{Introduction}

The consequences of the global financial crisis and corporate scandals have motivated regulators and the business communities to be more attentive towards corporate governance requirements across the globe. As a result, stakeholders in both corporate and non-commercial organisations sectors have placed focus on disclosure requirements in adherence to good corporate governance practices. This paradigm shift has seen increased awareness of the need for internal audit assurance on organisational corporate governance practices, internal controls and effective risk management (Soh \& Martinov-Bennie 2015). Corporate governance has become a priority for a long time now and requires a lot of effort and commitment from the management in most organisations. Shareholders need assurance that managers they have hired are acting in the best interest of the shareholders by maximising shareholder wealth and profit (Yuan, Cheng \& Ye 2016). On the contrary, the management needs to assess all the times that their set organisational goals and objectives are met according to the strategic plans. However, neither management nor shareholders can assert with certainty the effectiveness of the management decisions governing organisational risk management, governance and internal controls. As a result, the need for independent assurance that risk is managed effectively and internal controls are adequately operational is critical for the mission of organisations, both commercial and non-commercial (Payne 2008; Wang, Liu \& Chang 2011). 
The main role of internal auditing is to provide this needed assurance, over and above the evaluation and contribution to the improvement of corporate governance, management of risk and internal control processes guided by systematic and disciplined approaches (Wang et al. 2011). Therefore, the importance of the internal auditing as an integral part of every organisation's good corporate governance practice and assurance provision need not be over emphasised. The effectiveness of this nature of internal auditing hinges on full management support and commitment, competencies of the internal auditors and thelevel of internalauditors' independence (Al-Zeaud 2012; Gramling et al. 2004). Management needs to assure and demonstrate their full support for the internal auditing function by allowing and encouraging the independence of the internal auditors in their organisations. Management support and commitment are critical for ensuring the independent and objective internal auditing activities, such as identification of areas for performance improvement, quality improvement and emphasis on the implementation of the internal auditors' recommendations (Al-Matari, Al-Swidi \& Faudziah 2014). While internal auditors may be liable to top management in terms of the reporting structure, the discretion in determining the mandate, the scope and the methodology of conducting the internal auditing activities should lie with the auditors themselves without any degree of management interference (Al-Zeaud 2012; Caplan \& Kirschenheiter 2000). On the contrary, internal auditors' competence cannot be overlooked. In other words, internal auditors' independence alone is not enough (Hepworth and Noel 2002 cited in AlZeaud 2012). Internal auditors need to advance their competencies through professional training and development. Membership of relevant professional bodies such as professional auditors and accounting associations is handy in enhancing the competencies of the internal auditors, and thus enhances effective internal auditing (Gong et al. 2016).

Adequate amount of research acknowledges the importance of internal auditing and the role that it plays as a corporate governance tool in organisations. Because of this importance, most organisations, public and private, have institutionalised the institution of internal auditing in order to derive the benefits that accrue from such establishment (Hass, Abdolmohammadi \& Burnaby 2006). Badara and Saidin (2013a) intimate that effectiveness of internal auditing is critical and essential for decision-making purposes. Nevertheless, internal auditing function is no automatic panacea for curbing mismanagement. As a result, many studies have been conducted to establish the factors that impede the effectiveness of internal auditing in organisations (Al-Matari et al. 2014). Ineffective internal auditing function subjects management assertions about the truth and fairness of the organisations state of affairs to a lesser value (Badara \& Saidin 2013b). What this implies is that poorly organised systems result in loose internal controls, making the internal auditing function vulnerable to inefficiencies, compromises and corruption (Knechel \& Sharma 2012; Soh \& MartinovBennie 2015). In Ghana, the Internal Audit Agency (IAA), for example, ensures that the internal auditing function is effectively carried out. The Act of 658 of 2003 states that the internal auditors must exhibit the highest level of professionalism and perform internal auditing in accordance with generally accepted principles of internal auditing (GAPIA). They must make a balanced assessment of all issues of relevance to the work they are performing and also be honest and diligent.

In the same vein, one of Ghana's private universities has also realised the importance of the internal auditing function and has embraced the practice in its operations. Particularly, the responsible authority of one of Ghana's private universities and its various institutions believes in stewardship and accountability of resources as a fundamental biblical principle. Consequently, the responsible authority has implemented good principles for internal auditing for effective governance and efficient functioning of its institutions. Thus, adhering to the counsels of White (1915:452) stating that, 'administrative workers need to be fair and true' in their operations in 'connection with God's cause, and afford to deal on right principles'.

\section{Problem statement}

The role of internal auditing is very important in assuring the efficiency and effectiveness of an organisation's operations, as well as compliance with laws, rules, regulations, policies and procedures (Al-Matari et al. 2014). As a result, one of Ghana's private universities has established an internal audit department to guide its overall operations. Nevertheless, a fair number of lapses and flaws persist in the university's operations according to General Conference Audit Service (GCAS) audit reports since 2014, and that has raised questions regarding the relevance of the internal audit department and its credibility. The auditor's report of one of Ghana's private universities from 2014 to 2017 indicates flaws in the internal audit function. This proves that merely establishing an internal auditing department does not guarantee operational efficiency and effectiveness, reliability of financial reporting and compliance. Therefore, the purpose of this study is to explore the effect of management support and commitment, staff competence and independence of internal auditors on the effectiveness of organisational internal audit function.

\section{Research objectives}

The main purpose of this study was to investigate the impact of the antecedents of internal audit function effectiveness premised as management support and commitment; competence of internal audit staff; and independence of internal auditors at one of Ghana's private universities. The proposed specific or sub-objectives of the study are as follows:

- to examine the effect of the level of management support and commitment on the effectiveness of organisational internal audit function at a private university in Ghana

- to examine the effect of the level of competence of internal audit staff on the effectiveness of organisational internal audit function at a private university in Ghana

- to examine the effect of level of independence of the internal auditors on the effectiveness of organisational internal audit function at a private university in Ghana. 


\section{Justification for the study}

The findings of this study would help the university to achieve sound corporate governance in the school and improve the effectiveness of its internal audit. Management of the university would be able to assess the current situation of the effectiveness of the internal audit function and improve upon it. Other responsible institutions, which have the internal audit departments but are inactive, can also benefit from the study by knowing the importance of the internal audit department and their role in reviving it, and organisations that do not have internal audit departments might use this information as a guide in establishing the internal audit unit. Students conducting studies on internal audit function can take it up and conduct further research on the study or use it as a reference material. It would also help external auditors, investors or shareholders to make informed decisions.

\section{Literature and conceptual framework}

\section{Effectiveness of the internal audit system}

Different authors have defined the term 'effectiveness' in various ways. For example, Arena and Azzone (2009) cited in Badara and Saidin (2013) defined effectiveness as the capacity to obtain results that are consistent with targets'. According to Dittenhofer (2001), effectiveness is the achievement of internal auditing goals and objectives using the factor measures provided for determining such factors. In the work of Mihret and Yismaw (2007), internal audit effectiveness is defined as the extent to which an internal audit office meets it's supposed objective or the extent to which it meets the intended outcome'.

All the three authors defined effectiveness regarding achieving the internal auditing (IA) goals and objectives, though interpreted in different ways. Mihret and Yismaw (2007) described the characteristics of effective internal audit unit from the internal audit point of view. Effective IA is characterised by the following features:

- undertakes an independent evaluation of financial and operating systems and procedures

- contributes to the achievement of organisational goals

- needs management's commitment to implement recommendations

- provides useful recommendations for improvements as necessary

- affects negatively by lack of attention from management, which, in turn, adversely affects the auditee attributes.

\section{Management support and commitment}

Mihret and Yismaw (2007) found that the IA units are negatively impacted by inadequate management support and commitment, whose net effects are adverse IA attributes. Management support and commitment are the most critical factors in any organisational environment (Saud \& Marchand 2012). The effectiveness of IA hinges on the full support and commitment of organisational managers to create a conducive environment for the organisation's activities and success of the IA mandate. Management support and commitment are also dependent on the attitude of the board of directors towards the work of the internal auditors. The board should regularly communicate directly with the head of the IA department. The IA charter suggests that the board should communicate with the head of the IA at least once a year. The communication should focus on strengthening the institution of internal auditor independence. Management is expected to demonstrate their full support to the IA function through emphasis on the importance of internal auditor independence and objectivity of the IA function.

There is need for management to identify areas for performance improvement in the organisation and ensure quality control through implementation of the IA recommendations (Al-Matari et al. 2014; Gong et al. 2016). As Mihret and Yismaw (2007) reiterate in their study that management support and commitment to the function of IA are naturally a quid pro quo for effective IA. An earlier study by Sarens and Beelde (2006) and also supported by Aliyi (2016) concluded that IA and management are interdependent units in the organisation which need to work together to achieve organisational goals. Furthermore, implementation of the IA recommendations depends on the attitude of the management, which has to remain positive all the times (Krishnan \& Yang 2009). Al-Matari et al. (2014) suggest that IA is as useful as management allows it to be. This assertion is motivated by the findings of their study. Such an attitude by management defies the fundamental principles of IA and what IA stands for (Alzeban \& Sawan 2013). The results of this study and the highlighted earlier studies explain and support why Saud and Marchand (2012) emphatically underpin management support and commitment as possibly the most critical factors in the organisational environment. The authors further emphasised that the effectiveness of IA largely depends on full involvement of management and fulfilment of requirements (Munsif, Raghunandan \& Rama 2012).

In reality, IA is as important and useful as far as the management allows it to be (Admiraal 2015). According to Alzeban and Sawan (2013), the IA departments tend to suffer from inadequate senior management support and commitment. When, for example, the IA reports are critical of certain aspects of organisation's management actions and activities, there is a tendency of the management to want to take no action and hide behind organisation-related political reasons. When that happens, the IA function is undermined and its effectiveness reduced (Gray and Manson 2000 cited in Admiraal 2015). Mihret and Yismaw (2007) suggest that the failure of management to implement the IA recommendations does not only have far-reaching implications on the internal auditing effectiveness, but also dampens the internal auditor's spirit and zeal to improve IA quality and their commitment is compromised (Van Gansberghe 2005 cited in Aikins 2011). The author goes further to intimate that implementation of IA recommendations is critical to achieving IA effectiveness in organisations. According to Mihret and Yismaw (2007), the IA findings and 
recommendations do not serve any purpose as long as there is no management support and commitment to ensure that the recommendations are implemented across the organisation. The results of these studies infer that naturally, the profession of IA tends to suffer, as more people find it unattractive because of the lack of management support and commitment to implementation of the IA recommendations. Internal auditors get discouraged and tend to demonstrate low professionalism in their IA appointments as they feel they are not contributing towards organisational goals (Chen, Su \& Wu 2010). Therefore, the importance of management support and commitment to the function of the IA in the organisation does not need to be over emphasised. From the brief literature above, the study's hypothesis was developed as follows:

$\mathbf{H}_{\mathbf{1}}$ : There is a significant influence of the level of management support and commitment on the effectiveness of organisational internal audit function at a private university in Ghana.

\section{Competence of internal audit staff}

Internal auditors need to be always keep in mind the importance of maintaining audit objectivity and competence. They should always approach their work with professional scepticism regardless of their experience with and knowledge of the auditee (So \& Martinov-Bennie 2015). It is critical that the internal auditors refrain themselves from any personal professional involvement with the activities of the entity they are auditing. Professional scepticism dictates that internal auditors maintain an un-biased, impartial and sound mind-set as they fulfil their engagements. In other words, internal auditors should not be found wanting and guilt of any auditee operational responsibility. The organisational responsibility for good corporate governance lies with the management (Herz 2011; Knechel, Sharma \& Sharma 2012). Internal auditor competence involves the auditor jealously guarding objectivity and always avoiding impairing it (Shipman, Swanquist \& Whited 2017). Impairment of objectivity would naturally occur when the internal auditor comes back to conduct an assurance review of auditee activities that they would have had an experience of participating in their preparation in the past period which could be regarded as having potential to influence the internal auditor's judgement and cause auditor bias (Krishnan \& Yang 2009; Tewodros 2016). The IA charter explicitly makes it clear that the internal auditor should avoid accepting gifts and favours in any form from the auditee's workers, its clients and its business associates (Al-Matari et al. 2014; Bade \& Parkin 2016; Hertzog 2008). Objectivity and competence demand that internal auditors abide by the Code of Ethics, in order to avoid conflict of interests that they should always disclose any potential activity that can be misconstrued for some conflict of interest (Montclair State University 2012). Rotating the IA assignments among the IA staff could help mitigate against conflict of interests.

Internal auditing competence is developed through consented training, experience and relevant qualifications (Wang et al. 2011). It is the responsibility of the board of directors to ensure that internal auditors in their organisations are well and adequately resourced to be able to fulfil their mandate and have relevant and sound skills that are appropriate for their work (Stewart \& Subramaniam 2010). Constant and consistent training and skill development are critical for knowledge and expertise that the internal auditors require to deal with the ever-increasing challenges surmounting the IA environment (Knechel \& Sharma 2012). It is an IA charter requirement that internal auditors report to the board their work on organisational risk management, on corporate governance and internal controls bearing in mind the potential impact of these aspects on the performance of the organisations (Herz 2011; Knechel et al. 2012).

Internal auditors derive their power from their professional knowledge and expertise and ability to deploy situational leadership techniques. Like any other professional work and discourse, conduct of IA matures with time and the maturity of the auditee as well (Mitra, Song \& Yang 2015). There are quantum dispositions that internal auditors use in their conduct of duty depending on the level of maturity of the audited department. Accordingly, the internal auditors use 'telling' when the level of maturity of the audited department is low; they use 'selling' at mid-low levels of maturity, 'participating' when the level of maturity is mid-high and 'delegating' at high-maturity levels, respectively (Jun Lin, Xiao \& Tang 2008). Internal auditors are required to objectively report on every review that they undertake in a timely manner. Efficient reporting processes are very pertinent and critical to attaining high levels of IA effectiveness (KPMG 2004). The level of communication and style of reporting differs with the nature and type of the auditee and stakeholder (Tanyi, Raghunandan \& Barua 2010). For example, the internal auditor would communicate differently with the organisations' customers, the highranking management, the operational supervisors and the auditee's external auditors (Choi, Kim \& Raman 2017).

Upon completing the IA activities, the internal auditor is required to make a presentation of the IA findings with the relevant stakeholders prior to issuing the final IA report. The IA report should reflect auditee's opinions, objective audit findings, recommendations and management's responses to the issues raised in the internal audit report (Choi, Kim \& Raman 2017). Hepworth and Noel (2002) as cited in Al-Zeaud (2012) argue that staffing the IA department with professional personnel enhances the effectiveness of the IA function in organisations. Internal auditors are encouraged to consistently pursue continual professional development and growth through acquisition of professional membership with relevant professional bodies such as accounting associations at both national and international levels and seek to obtain world-class accreditation status. All these requirements imply enhancing and improving the effectiveness of IA processes (Yuan et al. 2016). Tewodros (2016) advises on the recruitment of competent and suitably qualified IA staff to support the IA of organisations.

While it is a fundamental principle that the success and effectiveness of IA as a corporate governance tool hinges on 
organisational management support and commitment, it is paramount according to the results of this study for IA staff to understand that their competence, an attribute that is internal auditor specific squarely lies with them (Al-Zeaud 2012; Bade \& Parkin 2016; Hepworth 2002; Hertzog 2008; Tewodros 2016). The private university's internal auditors could enhance their competence by seeking for accreditation and professional membership with relevant national and international accounting and auditing associations and also conduct themselves according to code of ethics and conduct (Aikins 2011; Van Gansberghe 2005; Mihret \& Yismaw 2007). It is important that the internal auditors pursue continual professional development through new knowledge acquisition and professional training (Aikins 2011).

$\mathbf{H}_{2}$ : There is a significant effect of the level of competence of internal audit staff on the effectiveness of organisational internal audit function at a private university in Ghana.

\section{Independence of the internal auditors}

Internal auditor independence is achieved when internal auditors are able to deliver impartial and unbiased judgement when they conduct their engagements. When management support and commitment are rendered to the IA staff to exercise their independence in the execution of their mandate, IA objectivity is guaranteed (Goodwin \& Yeo 2001 cited in Alzeban \& Sawan 2013). The degree of independence and autonomy of internal auditors is enshrined in the relevant statutory and auditing professional bodies, and it manifests itself in reporting structures within organisations (Enofe, Mgbame \& Osa-Erhabor 2013). That is, statutorily internal auditors report to the audit committee and/or to the top management of their organisation in order to ensure their independence and autonomy (KPMG 2004). The statutes also demand that the internal auditors be independent of the audited activities. In other words, internal auditors should not be part of the preparation of the financial statements of the entities they are supposed to audit (Quansah 2015). That is, the audited activities and the internal auditors should be independent of each other (Lai 2009). Their role is to provide third party assurance and opinion almost similar to that of the external auditors (Coram, Ferguson \& Moroney 2016; John 2015). It is solely the prerogative of the internal audit charter to determine the scope, methodology and the mandate of the internal auditors without interference from the organisational management (Halperin \& Lai 2015). Involvement of management in defining the scope of internal audit work compromises the independence of the internal auditors and renders the audited organisational activities vulnerable to management manipulation and covering up of illicit dealings of the management and potential misappropriation of organisational assets and resources. In other words, management can easily conceal their inappropriate actions and involvement in misappropriation of organisational resources rendering the scope of IA compromised (John 2015; Tanyi et al. 2010).
According to Dawuda, Ataribanam and Joseph (2017), the setup of the organisation's IA department and function needs to be as independent as possible. By organisational setting, the IA fundamentals refer to the physical position and status of the IA department in the organisation (Knechel et al. 2012). This includes the probity of the IA office in the organisation; the budget allocation or vote for the IA department in the organisation and the operational procedures and policy documents of the organisation. In addition, there should be available effective criteria to measure and evaluate the auditee's compliance to IA dictates of independence in particular (Ionescu 2008; Munsif et al. 2012). The criteria naturally provide the context in which the IA functions in the organisation. As a result, the IA organisational setting exerts some degree of influence on the overall effectiveness of the IA in the organisation (Dawuda et al. 2017). It therefore goes without saying that every organisation's IA setting should enable the internal auditors to execute their tasks without any impediment (Zain et al. 2004). With clear organisational IA setting in terms of an effective IA committee and other relevant structures, the effectiveness of the IA function is guaranteed (Lee, Mande \& Son 2009). In some organisations, because of their nature, the IA charter clearly establishes the prerequisite independence of the IA function by providing for dual-reporting structural relationship between the organisational management and the organisation's most senior oversight group charged with the governance of the organisation (Bartov \& Konichitchki 2017; Cahan \& Sun 2015). The IA charter explains clearly that internal auditors have a right to access all the organisational records relevant to the execution of their duties and they should have unrestricted access to the organisational personnel (Ljubisavljević \& Jovanović 2011; Payne 2008). They should be able to freely exercise appropriate probing techniques in their inquiry of the organisational staff without any prohibition (Mitra et al. 2015; Shipman et al. 2017). Organisations are obliged to establish the IA mandates through written auditing charters that define the purpose, the authority and the responsibilities of the internal auditors and support for their independence and objectivity within the organisations (Chan \& Wu 2011; Lai 2009). It is clear from the results of several studies in conformity with each other that the management at the university demonstrate their support for the IA unit by ensuring that the internal auditors have the autonomy to decide the scope of their audit work and how to execute it (Al-Matari et al. 2014). It is the responsibility of the IA committee and top management to guarantee the independence of the internal auditors by regularly revising the IA charter and IA mandate (Jun Lin et al. 2008). The independence of internal auditors is important for achieving IA objectivity and thus effectiveness of IA in general (Al-Matari et al. 2014; Lee et al. 2009). Thus, the study hypothesised as follows:

$\mathbf{H}_{3}$ : There is a significant effect of the level of independence of the internal auditors on the effectiveness of organisational internal audit function at a private university in Ghana. 


\section{Conceptual framework}

This study examined the factors affecting the effectiveness of an internal audit unit at one of Ghana's private universities. The researcher believes that if management provides the IA department with an independent position inside an organisation, it will have a positive influence on the effectiveness of IA in the private university. Also, the researcher believes that the competence level of the auditors in terms of experience and qualification plays an active role in implementing effective governance and controls in the university. More so, topmanagement commitment to ensuring effective IA system has a positive influence on the IA unit. Thus, this study sought to assess the relationship between the internal audit function and its role in minimising and preventing fraud in an organisation, avoidance of financial fraud, minimising qualified reports as well as preventing misappropriation of funds through effective internal controls as stated in the third chapter of the Seventh Day Adventist (SDA) Accounting Manual (2011). The conceptual framework of the study is presented in Figure 1.

\section{Methodology Research design}

This study was a cross-sectional quantitative research that used causal research design to examine the antecedents for effectiveness of organisational IA function at a private university in Ghana.

\section{Population and sampling procedure}

The target population comprised senior administration employees at different levels and departments from the three campuses of the selected private university in Ghana, namely, Accra, Kumasi and Techiman. Specifically, the population targeted included senior lecturers, departmental heads, deans and administration staff. The departments included the registry, finance, human resource, and school of education, school of business, school of science, graduate department and the IA department of the private university making a total target population of 480 .

The researchers adopted the systematic random sampling technique in selecting the respondents for the purposes of this study. This was to ensure that each respondent had an equal chance of being selected. The sample size was determined using the sample size determination method proposed by Van Dalen (1979). In his descriptive research on feelings and knowledge of HIV / AIDS awareness, Van Dalen states that the sample should be between $10 \%$ and $20 \%$. Because this population under study was heterogeneous (three campuses with different departments to select respondents from), the researchers chose a much higher percentage of $52 \%$. This amounted to a sample size of 250 respondents.

\section{Instrumentation}

The main instrument for data collection was a structured questionnaire comprising closed-ended questions. The questionnaire had four sections. Section A focussed on the demographic information of the respondents. Section $B$ focussed on the effectiveness of organisational IA, Section C measured the construct level of management support and commitment at the university. Section D covered the competence of IA staff and Section E dealt with the level of independence of the internal auditors at the private university. Furthermore, the researchers adopted the Likert linear scale type questions with a rating of $1-7$, implying strongly disagree, disagree, somewhat disagree, undecided, somewhat agree, agree and strongly agree.

\section{Ethical consideration}

Ethical clearance to conduct the study was obtained from Valley View University, January 18, 2019. No reference number was assigned at the time.

\section{Results and discussion Validity and reliability of instrument}

To ensure that the instrument would measure what it is supposed to measure, the instrument was checked for validity. The validity of the data collection instruments was ensured with the help of experts and advisors who vetted the questionnaire. To obtain the reliability of the instrument, a pilot study was administered to 25 respondents within the three campuses of the private university. The selection of the respondents for the pilot study is justified by Hertzog (2008) who stated a $10 \%$ strength of the study sample used for the study. For the sample size of 250 respondents, 25 respondents were therefore selected for the pilot study. Reliability of the instrument was ensured by testing the values (alpha values) as recommended by Cronbach (1946). The alpha values for the reliability test were 0.71 for competence of internal audit staff, 0.87 for level of independence of the IA, 0.81 for management support and commitment and 0.79 for effectiveness of the internal audit function.

\section{Method of data analysis}

Both descriptive and inferential statistics were used for the analyses of the data. For instance, percentages and frequencies were used to analyse respondents' demographic characteristics. Furthermore, means and standard deviations, correlations and multiple regression analyses were used to address the research objectives. The study used the Statistical

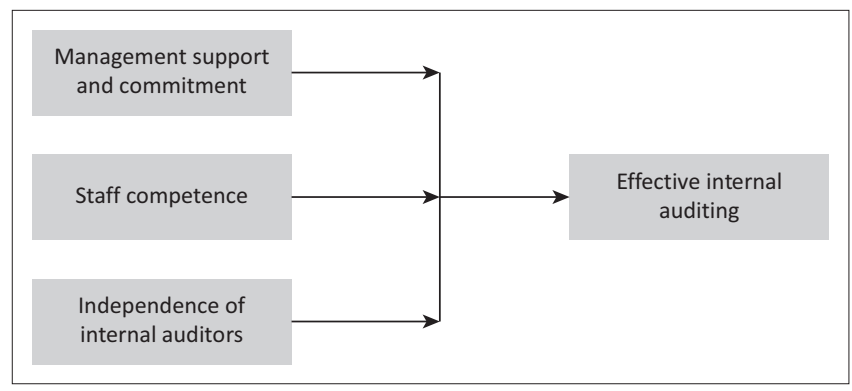

FIGURE 1: Conceptual framework for the study. 
Package for Social Science (SPSS) software version 22 for the analysis.

\section{Demographic characteristics of the respondents}

This section covers demographics of the respondents related to gender, educational level, working experience and category of staff. The result is indicated in Table 1.

Firstly, the study ascertained the gender distribution of the respondents. The results indicated in Table 2 show that out of the total 250 respondents, 152 representing $60.8 \%$ are males while 98 representing $39.2 \%$ are females. More males therefore participated in the study than females. The results are, however, representative of the staff in the private university because the males outnumber the females. With regard to educational level, 45 respondents representing $18 \%$ of the staff have diploma and Higher National Diploma (HND) certificates, 88 respondents representing $35.2 \%$ are undergraduates, 106 respondents representing 42.4\% are postgraduates and 11 respondents constituting 4.4\% have their doctorates or PhD certificates.

The study also included nine respondents constituting 3.6\% who had worked for less than 3 years, 82 respondents constituting $32.8 \%$ of the staff indicating that they had worked between 3 and 5 years. Forty-eight respondents constituting $19.2 \%$ had worked for 6-8 years, 40 respondents constituting $16 \%$ had worked for 9-11 years, 41 respondents constituting $16.4 \%$ had worked for $12-14$ years and 30 respondents constituting $12 \%$ had worked for more than 14 years. The majority of the respondents had worked in the university for more years (at least more than 3 years) and hence they were expected to know the internal control processes of the university.

Considering the category of staff who took part in the study, 95 respondents constituting 38\% comprised senior teaching staff, 35 respondents constituting 14\% were departmental heads and deans, 88 respondents representing $35.2 \%$ were accounts officers and 32 respondents constituting $12.8 \%$ were categorised among other staff except those mentioned. Respondents were therefore selected from different departments of the private university. This minimised the effect of biases on the results.

\section{Preliminary data analysis}

This section deals with the skewness and kurtosis values of the variables.

The normality of the data obtained for the study was verified. This was verified to detect outliers in the data and to ensure that the data are normally distributed. Data are said to be normally distributed when the skewness and kurtosis values fall within 2 and -2 (Tabachnick \& Fidell 2007). Table 2 shows that all the skewness and Kurtosis values were within the
TABLE 1: Demographic data of respondents.

\begin{tabular}{llcc}
\hline Questions & Categories & Number & Percentage \\
\hline Gender & Male & 152 & 60.8 \\
& Female & 98 & 39.2 \\
& Total & 250 & 100 \\
Educational level & Diploma or HND & 45 & 18.0 \\
& Undergraduate & 88 & 35.2 \\
& Postgraduate & 106 & 42.4 \\
& Doctorate or PhD & 11 & 4.4 \\
& Total & 250 & 100 \\
Working experience & Less than 3 years & 9 & 3.6 \\
& 3-5 years & 82 & 32.8 \\
& 6-8 years & 48 & 19.2 \\
& 9-11 years & 40 & 16.0 \\
& 12-14 years & 41 & 16.4 \\
& More than 14 years & 30 & 12.0 \\
& Total & 250 & 100 \\
& Teaching staff & 95 & 38.0 \\
& Departmental head & 35 & 14.0 \\
& Accounts officer & 88 & 35.2 \\
& Other staffs & 32 & 12.8 \\
& Total & 250 & 100 \\
\hline
\end{tabular}

HND, Higher National Diploma.

TABLE 2: An analysis of the skewness and kurtosis values of the variables.

\begin{tabular}{lcc}
\hline Variable & Skewness & Kurtosis \\
\hline Management support and commitment & -0.808 & -0.569 \\
Competence of IA staff & -0.666 & 0.113 \\
Level of independence of IA staff & -0.550 & 1.865 \\
Effectiveness of IA function & -1.221 & 0.303 \\
\hline
\end{tabular}

Source: Field survey in 2018

IA, internal auditing.

normal range, indicating that the data used in this study were normally distributed.

\section{Descriptive statistics}

Furthermore, Table 3 shows the descriptive statistics of the key variables. The variables were evaluated from 1 (strongly disagree) to 7 (strongly agree) using Table 3 for evaluation and interpretation.

The results in Table 3 indicate that the item or variable with the highest ratings was the effectiveness of the IA function with a mean value of 6.44 and standard deviation of 0.863 . The lower standard deviation value is an indication that the observations do not deviate much from the mean value of 6.44 . The high mean value recorded is an endorsement by respondents that the IA function of the private university is effective to a satisfactory extent. The results also indicate that respondents consider that the IA staff are independent and effective. The least rating by the respondents was given for the support and commitment of management of the private university to the IA unit with a mean value of 4.80 and standard deviation of 1.679 .

\section{Correlation and hypotheses testing}

Pearson's bivariate correlation analysis was initially conducted to determine the relationships between the independent variable and the dependent variables before 
proceeding to the regression analysis. Table 4 shows the correlation results.

The results in Table 4 show the relationship among the variables. The results indicate a positive relationship between the independent variables and the dependent variable. Thus, there is a positive correlation between the overall effectiveness of the internal audit function and management support and commitment $\left(r=0.388^{*}, p<0.01\right)$.

The hypothesis $\left(\mathrm{H}_{1}\right)$ : There is a significant influence of the level of management support and commitment on the effectiveness of organisational internal audit function at a private university in Ghana is statistically supported.

The results indicate a positive relationship between the competences of IA staff $\left(r=0.361^{*}, p<0.01\right)$ and the overall effectiveness of the internal audit function at the private university. Thus, statistically supporting the hypothesis $\left(\mathrm{H}_{2}\right)$ : there is a significant effect of the level of competence of internal audit staff on the effectiveness of organisational internal audit function at a private university in Ghana.

The level of independence of IA staff also reflects a positive statistical relationship with the overall effectiveness of the internal audit function at the private university $\left(r=0.441^{*}\right.$, $p<0.01$ ). As a result statistically supporting the hypothesis $\left(\mathrm{H}_{3}\right)$ : there is a significant effect of the level of independence of the internal auditors on the effectiveness of organisational internal audit function at a private university in Ghana.

TABLE 3: Descriptive statistics of variables.

\begin{tabular}{lccc}
\hline Variable & $N$ & Mean & $\begin{array}{c}\text { Standard } \\
\text { deviation }\end{array}$ \\
\hline Management support and commitment & 250 & 4.80 & 1.679 \\
Competence of IA staff & 250 & 6.00 & 1.132 \\
Level of independence of IA staff & 250 & 6.05 & 1.032 \\
Effectiveness of IA function & 250 & 6.44 & 0.863 \\
\hline
\end{tabular}

Note: Interval scale of 1.00-1.49 = strongly disagree; $1.50-2.49=$ somewhat disagree; 2.50 $3.49=$ disagree; $3.50-4.49=$ undecided; $4.50-5.49=$ agree; $5.50-6.49=$ somewhat agree; $6.50-7.00=$ strongly agree

IA, internal auditing.

TABLE 4: Correlation analysis of the variables.

\begin{tabular}{lcccc}
\hline Variable & MSC & CIAS & LIIAS & EIAF \\
\hline MSC & & & & \\
Person's correlation & 1.000 & $0.386^{*}$ & $0.178^{* *}$ & $0.388^{* *}$ \\
Sig. (one-tailed) & 1.000 & 0.023 & 0.000 & 0.000 \\
CIAS & & & & \\
Person's correlation & $0.386^{*}$ & 1.000 & $0.066^{*}$ & $0.361^{* *}$ \\
Sig. (one-tailed) & 0.023 & 1.000 & 0.041 & 0.000 \\
LIIAS & & & & \\
Person's correlation & $0.178^{* *}$ & $0.066^{*}$ & 1.000 & $0.441^{*}$ \\
Sig. (one-tailed) & 0.000 & 0.041 & 1.000 & 0.000 \\
EIAF & & & & \\
Person's correlation & $0.388^{* *}$ & $0.361^{* *}$ & $0.441^{*}$ & 1.000 \\
Sig. (one-tailed) & 0.000 & 0.000 & 0.000 & 1.000 \\
\hline
\end{tabular}

*, Correlation is significant at the 0.05 level (two-tailed).

**, Correlation is significant at the 0.01 level (two-tailed).

MSC, management support and commitment; CIAS, competence of internal auditing staff; EIAF, effectiveness of internal auditing function; LIIAS, level of independence of internal auditing staff.

\section{Multiple regression analyses}

The correlation coefficient of the model summary is 0.834 , as indicated in Table 5. Because this value is positive, it illustrates that there is a positive correlation between the predictor variables (competence of IA staff, level of independence of the IA staff, management support and commitment) and the criterion variable (effectiveness of the internal audit function). The adjusted $R^{2}$ value is 0.677 , indicating that approximately $67.7 \%$ of the total variation in effectiveness of the IA function can be explained by the predictor variables.

The statistical significance of the overall model is presented in Table 6. Thus, competence, level of independence of the IA staff, management support and commitment significantly influence the effectiveness of the internal audit function, $F(3,246)=32.795, p<0.0005)$. The individual predictors were examined further and the results are indicated in Table 7.

The statistical results in Table 7 show that competence of IA $(\beta=2.061, p<0.05)$, independence of internal auditing staff $(\beta=3.525, p<0.05)$, as well as management support and commitment $(\beta=3.036, p<0.05))$ have significant values less than 0.05 . This confirms that all the variables contribute to the effectiveness of IA. Hence, the alternate hypotheses of the study were accepted and the implication is that the level of management support and commitment, the competence of internal audit staff and the level of independence of the internal auditors significantly and positively affect the effectiveness of organisational IA function at the private university.

From the results above, all the predictor variables compare significantly in terms of the standardised beta coefficients. To fulfil the objective to examine the effect of the level of management support and commitment on the effectiveness of organisational internal audit function at the private university, the strength of the effect of the level of management support and commitment on the effectiveness of the internal audit function is measured by the standardised beta coefficient of value 3.036 .

The objective to examine the effect of the level of competence of internal audit staff on the effectiveness of organisational internal audit function at the private university was fulfilled

TABLE 5: Model summary of the regression.

\begin{tabular}{lcccc}
\hline Model & $\boldsymbol{R}$ & $\boldsymbol{R}^{\mathbf{2}}$ & Adjusted $\boldsymbol{R}^{\mathbf{2}}$ & Standard error \\
\hline 1 & $0.834 \dagger$ & 0.686 & 0.677 & 0.734 \\
\hline$\dagger$, Predictors: (Constant), management support and commitment, level of independence of
\end{tabular}

t. Predictors: (Constant), management support and commitment, level of independence of the internal auditing staff, competence of internal auditing staff.

TABLE 6: ANOVA results for the model.

\begin{tabular}{llccccc}
\hline Model & & Sum of squares & $d f$ & Mean squares & $\boldsymbol{F}$ & Sig. \\
\hline 1 & Regression & 53.022 & 3 & 17.674 & 32.795 & $0.00 \dagger^{\dagger}$ \\
& Residual & 132.578 & 246 & 0.539 & - & - \\
& Total & 185.600 & 249 & - & - & - \\
\hline
\end{tabular}

Note: Dependent variable: effectiveness of the internal audit function.

$\dagger$, Predictors: (constant), management support and commitment, level of independence of the internal auditing staff, competence of internal auditing staff. 
by the measurement of the standardised beta coefficient of value 2.061 reflecting the strength of the effect of the level of competence of internal audit staff on the effectiveness of internal audit function at the private university. However, the standardised beta coefficient of value 3.525 fulfils the objective to examine the effect of level of independence of the internal auditors on the effectiveness of organisational internal audit function at the private university.

The regression equation that expresses the linear relationships between the dependent variable and the independent variables is as shown below:

$\hat{y}=6.974_{0}+2.046 x_{1}+3.439 x_{2}+3.018 x$.

In this equation, $\hat{y}$ is the predicted value of the dependent variable (effectiveness of IA). Values of the $k$ independent variables are denoted by $\left(x_{1}=\right.$ management support and commitment; $x_{2}=$ level of independence of internal audit staff and $x_{3}=$ competence of internal audit staff).

Finally, we have the $b \mathrm{~s}\left(b_{0}=6.974 ; b_{1}=2.046 ; b_{2}=3.439\right.$; $\left.b_{3}=3.018\right)$. The $b$ s are constants termed regression coefficients.

\section{Managerial implications}

Management's positive attitude towards the function of IA at the university lies at the heart of the success of IA as a corporate governance tool. Anything to the contrary would impede the effectiveness of IA as a tool for corporate governance and thus adversely affect the mission of the private university. Full management support and commitment to the organisation's internal audit department, particularly guaranteeing the independence of the internal auditors, and sufficient resourcing of the internal auditing department are critical to the overall effectiveness of the internal audit function of the private university. The internal audit staff members need to be empowered in terms of skills and expertise appropriate to their job, and the internal auditors should receive consistent training and skill development they need in order to deal with the increasing challenges faced by the private university. The importance of internal auditor independence, a critical fundamental attribute of effective IA, need not be over emphasised. In other words, management's understanding of the importance of internal auditors being independent of any management interference is critical for the function of IA, in terms of objectivity and identification of areas that require quality improvement at the private university.

\section{Recommendations for further research in future}

In order to facilitate the generalisability of the study's results, there is a need to conduct further research in future, with a wider scope in terms of the sample spread and geographical location. This study was statistically limited to descriptive and inferential statistics using SPSS package. Potential future research could consider use and application of structural equation modelling (SEM) and/or principal component analysis (PCA) in order to enhance the quality of the statistical results and discovery of new insights on the phenomenon under study.

\section{Discussion}

The results are in conformation with earlier findings of Mihret and Yismaw (2007) who stated that the IA unit is affected negatively by lack of attention from management, which, in turn, adversely affects the auditee attributes. Management support and commitment to the IA unit are a natural quid pro quo for effective IA (Aliyi 2016). They stated that internal audit and management are interdependent units that should be working together to achieve organisational goals. This explains why Saud and Marchand (2012) stated emphatically that management's support is probably the most important factor in a company environment. They added that the effective nature of IA usually depends on the involvement of management and requirements. Management can demonstrate its support for an internal audit by emphasising the value of independent and objective internal auditing in identifying areas for improving performance quality and by implementing the recommendations of an internal audit unit. According to Al-Matari et al. (2014), an internal audit is as useful as the management allows it to be. The study by Alzeban and Sawan (2013) also supported this claim when they revealed that the IA department suffers because of less support from senior management. If internal auditors issue reports that are critical of certain parts of the organisation and management takes no action for political reasons, this would only serve to undermine the internal audit function and reduce its effectiveness (Aikins 2011). The author further submits that the implementation of audit recommendation is highly relevant to internal audit effectiveness.

After the audit activities end, internal auditors should discuss audit findings with audited departments, and then write audit reports according to the discussion. The audit report should include audited departments' opinions, positive audited findings, suggestions and audited departments' responses. Hepworth and Noel (2002) cited in Al-Zeaud (2012) argued that staffing professional employees increases

TABLE 7: Variable coefficients of the regression model.

\begin{tabular}{|c|c|c|c|c|c|c|}
\hline \multicolumn{2}{|c|}{ Model } & \multicolumn{2}{|c|}{ Unstandardised coefficients } & \multirow{2}{*}{$\frac{\text { Standardised coefficients }}{\text { Beta }}$} & \multirow[t]{2}{*}{$t$} & \multirow[t]{2}{*}{ Sig. } \\
\hline & & $B$ & Std. error & & & \\
\hline \multirow[t]{4}{*}{1} & (Constant) & 6.974 & 0.394 & - & 10.078 & 0.000 \\
\hline & Competence of internal auditing & 2.046 & 0.042 & 2.061 & 1.116 & 0.006 \\
\hline & Level of independence of internal auditing staff & 3.439 & 0.045 & 3.525 & 9.718 & 0.000 \\
\hline & Management support and commitment & 3.018 & 0.028 & 3.036 & 0.658 & 0.005 \\
\hline
\end{tabular}


effectiveness of IA, and that an internal auditor should pursue continual professional development by seeking membership of professional auditor and accountant associations both nationally and internationally and obtain world-class accreditation, All in all, this will help in improving effectiveness of the IA process. On the contrary, Tewodros (2016) advises that recruiting competent and well-qualified staff to support IA activities and departments is critical to the effectiveness of IA. From the study of Tewodros (2016), internal audit teams need suitably experienced, qualified and trained staff to produce the best advice and judgements for boards and management. Boards should ensure that internal audit work is sufficiently resourced to allow it to fulfil its mandate, that staffs in key positions have a recognised skill set appropriate to their functions and that staff receive the training and development they need to deal with the increasing challenges organisations are facing. PR5 also advised that the internal auditor should pursue continual professional development by seeking more knowledge, professional training and experience. There are various courses that the internal auditor can be enrolled in; both nationally and internationally and obtain excellent accreditation.

It was therefore not surprising that Ljubisavljević and Jovanović (2011) indicated that an internal audit makes a significant contribution to the achievement of organisational goals, and the implementation of strategies for their achievement. Therefore, the internal audit plays a major role in the provision of reliability, reality and integrity of financial and operational information that comes from different organisational units. Mostly, management utilises this audit information and it constitutes the basis on which appropriate business decisions are undertaken. Therefore, the success in the implementation of internal audit tasks depends on the independence of the internal audit unit; that is, the institutional management should in no way influence its work, information, conclusions and evaluations (Al-Matari et al. 2014). Along this line of argument, Al-Matari et al. (2014) stated that the IA functions to control the accounting system as well as assessing plans and procedures to determine weaknesses or defects in the systems and procedures used by the company; and to propose modifications and enhancements needed to ensure effective audit work.

\section{Conclusion}

The purpose of this study was to examine the effect of the level of management support and commitment; the level of competence of internal audit staff and the level of independence of the internal auditors on the effectiveness of organisational internal audit function at one of Ghana's private universities. The results indicated that the effect of the level of independence of the internal auditors had the highest strength of impact on the overall effectiveness of the internal audit function at the private university. This was followed by the effect of the level of management support and commitment, and the level of competence of the internal audit staff, respectively. The results also indicated that there are significant positive correlations between IA effectiveness, management support and commitment, competence of IA staff and the levels of independence of the internal auditors. Management support and commitment, competence of IA staff and levels of independence of internal auditors have a positive correlation with overall organisational internal audit effectiveness, and collectively the antecedents account for $67.7 \%$ of the effectiveness of the organisational internal audit function at the private university. The study extends the academic debate on IA practice as a tool for good corporate governance and management of the agency problem that prevails in non-profit organisations as well as corporate entities.

\section{Acknowledgements Competing interests}

The authors declare that they have no financial or personal relationships that may have inappropriately influenced them in writing this article.

\section{Authors' contributions}

B.N. is the lead and corresponding author and conducted the statistical analysis for the article as well. T.P. provided the academic guidance in the writing of this article. O.A.M. administered the data collection processes, coded the data for analysis and was involved in the data analysis as well.

\section{Funding information}

Funding for the study and page fees were obtained from the corresponding author's research fund obtained for the postdoctoral research fellowship allocated by the University of KwaZulu-Natal.

\section{Data availability statement}

Data sharing is not applicable to this article as no new data were created or analysed in this study.

\section{Disclaimer}

The authors declare that the views expressed in this article are their own and not an official position of the institutions.

\section{References}

Admiraal, W.J., 2015, 'Efficient risk management', Construction Management and Economics 98(10), 418.

Aikins, S.K., 2011, 'An examination of government internal audits' role in improving financial performance', Public Finance and Management 11(4), 306. https://doi. org/10.1108/17506200710779521

Aliyi, H., 2016, Factors that identify the effectiveness of internal audit in Oromia special zone surrounding finfinne administration finance and economic development, Addis Ababa University, Addis Ababa.

Al-Matari, E.M., Al-Swidi, A.K. \& Faudziah, H.B.F., 2014, 'The effect of the interna audit and firm performance: A proposed research framework', International Review of Management and Marketing 4(1), 34-41.

Al-Zeaud, H.A., 2012, 'Management support and its impact on performance of internal auditors at Jordanian public industrial shareholding companies', Global Journal of International Business Research 5(5), 52-64. 
Alzeban, A. \& Sawan, N., 2013, 'The role of internal audit function in the public secto context in Saudi Arabia', African Journal of Business Management 7(235) 443-454. https://doi.org/10.5897/AJBM12.1430

Ayson, P., 2010, Resourcing of management and administrative structures, Primary Principals Sabbatical.

Badara, M.S. \& Saidin, S.Z., 2013a, 'Impact of the effective internal control system on the internal audit effectiveness at local government level', Journal of Social and Development Sciences 4(1), 16-23. https://doi.org/10.5923/j.ijfa.20130202.05

Badara, M.S. \& Saidin, S.Z., 2013b, 'The journey so far on internal audit effectiveness: A calling for expansion', International Journal of Academic Research in Accounting Finance and Management Sciences 3(3), 340-351. https://doi.org/10.6007/ IJARAFMS/v3-i3/225

Bade, R. \& Parkin, M., 2016, Foundations of economics, 7th edn., Prentice-Hall, Amsterdam.

Bartov, E. \& Konichitchki, Y., 2017, 'SEC filings, regulatory deadlines, and capital market consequences', Accounting Horizons 31(4), 109-131. https://doi.org/ 10.2308/acch-51887

Cahan, S.F. \& Sun, J., 2015, 'The effect of audit experience on audit fees and audit quality', Journal of Accounting Auditing \& Finance 30(1), 78-100. https://doi. org/10.1177/0148558X14544503

Caplan, D.H. \& Kirschenheiter, M., 2000, 'Outsourcing and audit risk for internal audit services', Contemporary Accounting Research 17(3), 387-428. https://doi.org/ 10.1506/8CP5-XAYG-7U37-H7VR

Chan, K.H. \& Wu, D., 2011, 'Aggregate quasi rents and auditor independence: Evidence from audit firm mergers in China', Contemporary Accounting Research 28(1), 175-213. https://doi.org/10.1111/j.1911-3846.2010.01046.x

Chen, J.P.C., Su, X. \& Wu, X., 2010, 'Auditor changes following a Big 4 merger with a local Chinese firm: A case study', Auditing: A Journal of Practice \& Theory 29(1) 41-72. https://doi.org/10.2308/aud.2010.29.1.41

Choi, J.-H., Kim, S. \& Raman, K.K., 2017, 'Did the 1998 merger of Price Waterhouse and Coopers \& Lybrand increase audit quality?', Contemporary Accounting Research 34(2), 1071-1102. https://doi.org/10.1111/1911-3846.12290

Coram, P., Ferguson, C. \& Moroney, R., 2016, 'The value of internal audit in fraud detection', Accounting and Finance 48(4), 1-32.

Cronbach, L.J., 1946, 'Response sets and test validity', Educational and Psychological Measurement 6(4), 475-494. https://doi.org/10.1177/001316444600600405

Dawuda, A., Ataribanam, S. \& Joseph, A., 2017, 'An exploratory study on management support services and its effects on the quality service delivery of internal auditors in the Northern Ghana', International Journal of Accounting Research 5(2), 2-5. https://doi.org/10.4172/2472-114X.1000170

Dittenhofer, M., 2001, 'Internal auditing effectiveness: An expansion of present methods', Managerial Auditing Journal 16(8), 443-450. https://doi.org/10.1108/ EUM0000000006064

Enofe, A.O., Mgbame, J.C. \& Osa-Erhabor, V.E., 2013, 'The role of internal audit in effective management in public', Research Journal of Finance and Accounting $4(6)$ $162-168$

Gray, I. \& Manson, S., 2000, The audit process principles, practice and cases, 2nd edn., International Thomson Business, London.

Gong, Q., Li, O.Z., Lin, Y. \& Wu, L., 2016, 'On the benefits of audit market consolidation: Evidence form merged audit firms', The Accounting Review 91(2), 463-488. https://doi.org/10.2308/accr-51236

Gramling, A.A., Maletta, M.J., Schneider, A. \& Church, B.K., 2004, 'The role of the internal audit function in corporate governance: A synthesis of the extant internal auditing literature and directions for future research', Journal of Accounting Literature 23(1), 194-244.

Halperin, R. \& Lai, K.-W., 2015, 'The relation between auditor-provided tax service fees and audit fees after the Sarbanes-Oxley act: From the perspective of cross selling of services', Journal of Accounting Auditing \& Finance 30(3), 341-372. selling of services', Journal of Accounting Audit
https://doi.org/10.1177/0148558X14560900

Hass, S., Abdolmohammadi, M.J. \& Burnaby, P., 2006, 'The Americas literature review on internal auditing', Managerial Auditing Journal 21(8), 835-844. https://doi. org/10.1108/02686900610703778

Hepworth, N., 2002, 'The european experience of and attitudes to the developmen of international accounting standards', in V. Montesinos \& J. Manuel Vela (eds.) Innovations in Governmental Accounting, pp. 73-84, Kluwer, Dordrecht.

Hertzog, M.A., 2008, 'Considerations in determining sample size for pilot studies', Research in Nursing and Health 31(8), 180-191. https://doi.org/10.1002/nur

Herz, R., 2011, 'Renewed focus on mandatory auditor rotation', Compliance Week 1 (November), 38-39.

Institute of Internal Auditors (IIA), 2009, The role of internal auditing in enterprisewide risk management, pp. 1-8, Institute of Internal Auditors.

Ionescu, L., 2008, 'The appropriateness of an internal control system', Economics, Management, and Financial Markets 3(1), 90-94.

John, C., 2015, The audit committee's role in control and management of risk, No. 3 Center for Audit Quality, Washington DC.

Jun Lin, Z., Xiao, J.Z. \& Tang, Q., 2008, 'The roles, responsibilities and characteristics of audit committee in China', Accounting, Auditing \& Accountability Journal 21(5) 721-751. https://doi.org/10.1108/09513570810872987

Knechel, W.R. \& Sharma, D.S., 2012, 'Auditor-provided non-audit services and audit effectiveness and efficiency: Evidence from pre- and post-SOX audit report lags', Auditing: A Journal of Practice \& Theory 31(4), 85-114. https://doi.org/10.2308/ ajpt-10298
Knechel, W.R., Sharma, D.S. \& Sharma, V.D., 2012, 'Non-audit services and knowledge spillovers: Evidence from New Zealand', Journal of Business Finance \& Accounting 39(1 \& 2), 60-81. https://doi.org/10.1111/j.1468-5957.2011.02268.x

KPMG, 2004, KPMG Audit Committee Guide, KPMG South Africa, Johannesburg.

Krishnan, J. \& Yang, J.S., 2009, 'Recent trends in audit report and earnings announcement lags', Accounting Horizons 23(3), 265-288. https://doi.org/ 10.2308/acch.2009.23.3.265

Lai, K.-W., 2009, 'Does audit quality matter more for firms with high investment opportunities?', Journal of Accounting and Public Policy 28(1), 33-50. https://doi. org/10.1016/j.jaccpubpol.2008.11.002

Lee, H.-Y., Mande, V. \& Son, M., 2009, 'Do lengthy auditor tenure and the provision of non-audit services by the external auditor reduce audit report lag?', International JournalofAuditing13(2),87-104.https://doi.org/10.1111/j.1099-1123.2008.00406.x

Ljubisavljević, S. \& Jovanović, D., 2011, 'Empirical research on the internal audit position of companies in Serbia', Economic Annals 56(191), 123-141. https://doi. org/10.2298/EKA1191123

Mihret, D.G. \& Yismaw, A.W., 2007, 'Internal audit effectiveness: An Ethiopian public sector case study', Managerial Auditing 22(5), 470-484. https://doi.org/ sector case study', Manage
$10.1108 / 02686900710750757$

Mitra, S., Song, H. \& Yang, J.S., 2015, 'The effect of auditing standard no. 5 on audit report lags', Accounting Horizons 29(3), 507-527. https://doi.org/10.2308/acch51052

Montclair State University, 2012, Internal audit policy and procedures - Internal audit charter, Montclair State University, Montclair, viewed 17 February 2019, from http://www.montclair.edu/media/montclairedu/president/internalaudit/ internal-audit-procedures-manual.pdf.

Munsif, V., Raghunandan, K. \& Rama, D.V., 2012, 'Internal control reporting and audit report lags: Further evidence', Auditing: A Journal of Practice \& Theory 31(3), 203-218. https://doi.org/10.2308/ajpt-50190

Payne, J.L., 2008, 'The influence of audit firm specialization on analysts' forecast errors', Auditing: A Journal of Practice \& Theory 27(2), 109-136. https://doi. org/10.2308/aud.2008.27.2.109

Quansah, V.A., 2015, 'Internal audit practice and corporate governance at Ghana Post', Economy Transdisciplinary Cognition 16(1), 79-83, viewed 23 January 2019, from http://search.ebscohost.com/login.aspx?direct=true\&db=bth\&AN=905430 $68 \&$ lang=tr\&site=eds-live\&authtype=ip, uid.

Sarens, G. \& De Beelde, I., 2006, 'Internal auditors' perception about their role in risk management: A comparison between US and Belgian companies', Manageria Auditing Journal 21(1), 63-80. https://doi.org/10.1108/02686900610634766

Saud, S. \& Marchand, N., 2012, Contribution of internal audit in the achievement of corporate goals: A case of Sweden and Pakistan, Karlstad Business School, Melbourne.

SDA Accounting Manual, 2011, Seventh day adventist accounting manual for the year 2011, viewed 16 February 2019, from https://sunplus.adventist.org/wp-content/ uploads/2018/05/SDAAM_Jan_2011_Final.pdf

Shipman, J.E., Swanquist, Q.T. \& Whited, R.L., 2017, 'Propensity score matching in accounting research', The Accounting Review 92(1), 213-244. https://doi. org/10.2308/accr-51449

Soh, D.S.B. \& Martinov-Bennie, N., 2015, 'Internal auditors' perceptions of their role in environmental, social and governance assurance and consulting', Managerial Auditing Journal 30(1), 80-111. https://doi.org/10.1108/MAJ-08-2014-1075

Soh, D.S.B. \& Martinov-Bennie, N., 2015, 'The internal audit function: Perceptions of internal audit roles, effectiveness, and evaluation', Managerial Auditing Journa 26(7), 605-622.

Stewart, J. \& Subramaniam, N., 2010, 'Internal audit independence and objectivity: Emerging research opportunities', Managerial Auditing Journal 25(4), 328-360. https://doi.org/10.1108/02686901011034162

Tabachnick, B.G. \& Fidell, L.S., 2007, Using multivariate statistics, 2nd edn., Harper Collins Publishers, Northridge, CA. https://doi.org/10.1037/022267

Tanyi, P., Raghunandan, K. \& Barua, A., 2010, 'Audit report lags after voluntary and involuntary auditor change', Accounting Horizons 24(4), 671-688. https://doi. involuntary auditor change', Accou
org/10.2308/acch.2010.24.4.671

Tewodros, T., 2016, Assessment on challenges of internal audit practice of St Mary's University, Walden University, Minneapolis, MN.

Van Dalen, D.B., 1979, Understanding educational research: An introduction, 4th edn. McGraw-Hill Book Company, New York. https://doi.org/10.1177/0013164 48004000331

Van Gansberghe, C.N., 2005, Internal audit: Finding its place in public finance management, World Bank Paper 37246, World Bank, Washington DC.

Wang, T., Liu, C. \& Chang, C.-H.J., 2011, 'CPA-firm merger: An investigation of audit quality', European Accounting Review 20(4), 727-761. https://doi.org/10.1080/0 9638180.2011.600485

White, E.G., 1915, Gospel workers, 1915 edn., Review and herald publishing association, Washington DC

Yuan, R., Cheng, Y. \& Ye, K., 2016, 'Auditor industry specialization and discretionary accruals: The role of client strategy', The International Journal of Accounting 51(2), 217-239. https://doi.org/10.1016/j.intacc.2016.04.003

Zain, M., Kassim, M.M. \& Mokhtar, E., 2004, 'Use of information technology and information systems for organisational agility in Malaysian firms', Singapore Management Review 25(1), 69-84. 